\title{
New Administration, New Immigration Regime: Do Parties Matter After All? A UK Case Study
}

\section{Abstract}

Research on the impact of parties on public policy, and on immigration policy in particular, often finds limited evidence of partisan influence. In this paper, we examine immigration policymaking in the UK coalition government. Our case provides evidence that parties in government can have more of an impact on policy than previous studies acknowledge, but this only becomes apparent when we open up the 'black box' between election outcomes and policy outputs. By examining how, when and why election pledges are turned into government policies, we show that partisan influence depends not only on dynamics between the coalition partners, but how these dynamics interact with interdepartmental conflicts and lobbying by organized interests. In-depth process tracing allows us to see these complex dynamics, which easily get lost in large $n$ comparisons of pledges and outputs, let alone outcomes.

\section{Introduction}

There is an intriguing paradox at the heart of the 'do parties matter' debate (see Schmidt, 1996; see also Imbeau et al., 2001). The answer, at least according to decades of increasingly sophisticated cross-national comparative research would seem to be 'politics hasn't mattered - much' (Caul and Gray, 2000) and may matter even less nowadays than it did before (Mair, 2008). Yet most of us who read that research - and no doubt many of those who conduct it - could readily reel off a long list of examples from our own lived experience where a change of government triggered a perceptible, and sometimes even immediate, shift in policy.

One explanation for this paradox is that most comparative work in the 'does politics matter?' debate is quantitative. Research in this tradition, whatever its critics like to think, is not necessarily condemned to uncover only scant or trivially significant partisan effects: crunching the numbers can, after all, reveal that something really is going on even in sectors where, for example, one might 
expect internationalization and economic constraints to limit parties' impact (see for example, Knill et al., 2010). Nevertheless, quantitative studies do find themselves at something of a disadvantage in one important sense, namely that they often focus not so much on the relationship between inputs (manifesto pledges, for example) and outputs (government policies, legislated and otherwise), as on the relationship between inputs and outcomes (ie whether those policies have their desired result). While understandable in certain respects, this approach runs the risk of proving something of a fool's errand. After all, as a policy moves from pledge to programme, and then from implementation to evaluation, any partisan effect is almost bound to be diluted in the process. That doesn't mean, however, that politics never mattered in the first place.

Another reason for our difficulty in proving that politics, and more specifically parties, matter even when we know (or at least believe) intuitively that they do is the fact that people who study those parties know relatively little about the governmental policy process, while people who study the policy process or political economy know relatively little about parties (see Streek and Thelen, 2005). For party scholars, policy is mostly about positioning, about attracting votes and winning and staying in power. For policy analysts, parties may well come up with policy ideas for electoral reasons but they are quickly left behind, and often left out of the account, as bureaucrats and interest groups, as well as sheer inertia, lead to the making of 'policy without politicians' (Page 2012, 2011; cf Richardson and Jordan 1979, Rose and Davies, 1994). The study of partisan influence in policymaking, in effect, risks falling between these two stools.

In a way, both sets of scholars are equally wrong and equally right - which suggests an obvious way forward: party and policy analysts should get together and then get into the nitty-gritty, often qualitative work of picking a set of pledges, checking what gets lost in translation when thoughts are turned into words and words become deeds, and then making an informed judgement call on whether the party or parties in question did or did not make a difference. In doing so, they should bear in mind that the ability to turn political dreams into policy realities comes pretty close to 
alchemy and that politicians are doing well if they manage to turn gold into base metal let alone base metal into gold. As the economist J. K. Galbraith (1969) reminds us, it may be too much even to suggest that 'politics is the art of the impossible' since it often 'consists in choosing between the disastrous and the unpalatable.'

In this article we argue that parties in government have more of an impact on policy outputs than previous studies assume and acknowledge, but that this is only evident when we open up the 'black box' between election outcomes and policy outcomes in some detail. Only by doing that can we understand how, when and why manifesto and election pledges are turned into government policies. In a complex interplay between politicians, civil servants, and non-governmental actors what matters for partisan influence is not simply a change of administration, although that is important, but the relative strength and influence of various interest groups and government departments too. There are complex interaction effects here, in which partisan influence may be concentrated or diluted. In the context of coalition governments, for example, the influence of different government departments on policy depends not just on long-established ministerial hierarchies but on which party sits atop and astride those ministries.

We begin by providing a rationale for our focus on immigration policy, for selecting as our case the Conservative-Liberal Democrat coalition which took office in the UK in 2010, and for our qualitative approach. We then proceed in three stages. First, we evaluate and explain the transition from the starkly different election pledges made by the two parties in the 2010 campaign to the coalition's programme for government. Second, we summarise the government's immigration policies to date. Third, we examine the process by which the coalition agreement has been converted into policy outputs, examining the role of interest groups and intra-coalition dynamics in this process. In a concluding section, we discuss the relevance of our findings for debates about partisan influence on public policy in general and immigration policy in particular.

Focus, approach, and case 
There is widespread agreement among scholars that whether a particular polity can be classified, following Lijphart (2012), as a majoritarian or a consensual democracy is important when trying to uncover whether parties make a difference. This is primarily because the single party majority governments that occur more frequently in the majoritarian type not only do not have to compromise with coalition partners but face legislatures that, generally speaking, are far weaker. Coalition politics adds another filter through which political fantasies must pass if they are to become policy realities. Coalition government also adds a party political twist to interdepartmental conflict, as partisan differences often become intertwined with the functional division of labour and interests between different government ministries. Each of those ministries is likely to have institutional memories, interests and agendas of its own that may not sit well with the intentions of whichever elected politician is put in charge of it (see Laver and Shepsle, 1994; see also Thomson, 2001). And in a coalition government, whoever is formally in charge will almost certainly have to work with junior ministers from another party (or parties) who have been deliberately placed there to keep an eye on them (see Lipsmeyer and Pierce, 2011).

There is equally widespread agreement among scholars specialising in migration policy that the governments of liberal democratic states face a number of obstacles when it comes to controlling immigration - as many of their citizens would apparently like them to do (e.g. Ivarsflaten, 2005; McLaren and Johnson, 2007; Sides and Citrin 2007). In terms of economic migrants, businesses and other pro-immigration 'clients', such as the education sector, often lobby governments and may exercise an expansionist influence on policy compared to the restrictive preferences of the public (Freeman, 1995); although as we show below the effect of these clients may in fact vary between immigration policy sub-fields. Furthermore, in the context of the European Union, many seeking to enter are EU citizens exercising free movement rights, who cannot therefore be excluded. In the areas of forced and family migration, court rulings drawing on international and national laws often stymie executives' attempts to exclude 'unwanted' immigrants (Joppke, 1998). And when governments seek to deport unauthorised immigrants, they often face obstacles to removal in the 
form of legal judgements and public counter-mobilisation (Ellermann, 2009). Policy-makers are also bound to take account of (or at least pay lip service to) the evidence provided by social, legal and economic research, at least some of which casts doubt upon their capacity to control flows and, indeed, the advisability of so doing, although there is of course an extent to which governments commission research not so much to act on it, but rather to legitimise their existing plans and preferences (see Boswell, 2009).

Given all this, it is no surprise that many observers were deeply sceptical about the UK government's ability to make good on the promise it made in May 2010 to reduce net migration. This scepticism was partly informed by the fact that this was a coalition rather than a single party majority government. The senior partner in the coalition was the Conservative Party - a party with a long record of wanting to appear tough on this issue that had only been partly played down by its relatively new leader, David Cameron, who, while he was concerned lest too hard a line alienate well-heeled, well-educated voters, was also determined to make the most of the lead over Labour which that hard line gave his party among the rest of the electorate (see Bale, 2013; Bale et al, 2011). The Tories' junior partners were the Liberal Democrats - a party which had campaigned at the general election in 2010 on a platform that called for the regularisation of significant numbers of illegal immigrants. Although the Conservatives ensured that they would control the Home Office, the UK's equivalent of what in most continental European democracies is known as the Interior Ministry, it would have to reckon with the Department of Business, Innovation and Skills, which would be headed up by a senior - indeed, virtually 'unsackable' - Liberal Democrat who, as a selfconfessed social democrat, had little compunction about voicing his ideological and practical doubts as to the merits of Conservative policies across the piece. Furthermore, any attempt to make significant reductions in numbers coming into and staying in the UK would run up against many of the obstacles identified above, namely employers and educational institutions with an interest in the entry of workers and students, and pro-migrant groups willing to take cases to courts using human rights legislation that militates against restriction. Last, but by no means least, the commitment to 
reduce net migration seemed a hostage to fortune since that figure is just as influenced by emigration (over which the government has no control) as it is by immigration, and furthermore at least one important component of immigration - the free movement of EU citizens - cannot be restricted so long as the UK remains in the EU.

In spite of all these obstacles, net migration did initially fall and immigration control was seen as one of the government's few success stories, not least by those pressure groups and right-wing newspapers that had attacked the previous Labour government (see, for example, Migration Watch, 2013 and Pollard, 2013). However, as the recent 30 percent increase in the figures up to 212,000 in the year to September 2013 show, even with restrictive policies in place, factors outside of the government's control (in this case reduced emigration and a rise in EU citizens arriving from the jobless economies of Spain, Portugal, Italy and Greece) meant that achieving the outcome promised in 2010 was always going to be difficult. Notwithstanding this, as we discuss below, policy tightening has had an appreciable impact on inflows. Politics, in other words, seems to have made a difference - and in what were some exceptionally unpropitious circumstances.

This unexpected success - if success is what it is - makes the UK a fascinating case study. As in many other states, public opinion in the UK, while more nuanced than often imagined (see Ashcroft, 2013; see also Mclaren and Johnson, 2007) has turned decidedly negative on immigration and there is some evidence to suggest that such shifts do - thermostatically, as it were (Jennings, 2010) eventually encourage policy-makers to respond to them (see also Ford et al., forthcoming). And unlike most states, UK governments are - in normal times - constitutionally and politically empowered (by a tradition of strong executives facing relatively few legislative or judicial constraints) to act decisively if they so choose. However, the fact that from May 2010 onwards the country was run by a coalition rather than a single-party majority government, meant that these were not normal times: instead of governing alone, as it had got used to doing in the post-war period, a centre-right party with a restrictionist agenda was obliged to share the spoils with a party widely seen as being as 
being on the centre-left, not least because its platform on immigration and asylum was decidedly liberal.

Our approach to that case study - and to the puzzle at its heart - is essentially institutionalist, and our method is process tracing - an approach based on documentary sources and (necessarily offthe-record) interviews with senior government advisors and officials, which is well-suited to an attempt to comprehend complex causation (George and Bennett, 2005; see also Beach and Pedersen, 2012). Using this approach, we turn first to an examination of the way in which the two parties' immigration policies made it into the programme of the coalition which the Conservative Party formed with the Liberal Democrats in May 2010.

\section{From election commitments to coalition agreement}

In the context of coalition governments, the first stage of understanding how and indeed whether an individual party's position is fed into the governmental policymaking process is the negotiations that precede the formation of a coalition. If we are to trace partisan influence we need to account for this initial stage of bargaining and compromise; and if we want to understand why some partisan commitments make it while others do not, we need to scrutinise the process of coalition formation. Thus we begin by describing the Conservatives' and Liberal Democrats' very different commitments on immigration during the 2010 election campaign, consider what did and what did not make it into the coalition agreement, and then ask why. As will be seen, the substantial differences between the two parties on this issue were resolved overwhelmingly in favour of the majority partner.

The Conservative's headline commitment on immigration, first made by David Cameron in a television interview and then included in the Party's 2010 election manifesto, was to cut the level of net migration (immigration minus emigration) to 'tens of thousands a year, not hundreds of thousands' by the end of the Parliament in 2015 (Conservative Party, 2010: 21). Given that net migration at that time was 252,000 , a national record, this meant more than halving net inflows in 
the space of just five years. It was nothing if not a bold promise. Over the previous decade, the Labour government had overseen a substantial increase in net migration, at least partly caused by their liberalisation of work-related and student migration routes and, crucially, the decision to allow A8 citizens access to the UK labour market in 2004. Immigration had become increasingly salient and public opinion had hardened. According to one 2010 survey, 65 per cent of British citizens viewed immigration as more of a problem than an opportunity and 63 per cent said that a party's position on immigration would affect how they voted (Transatlantic Trends, 2010).

The 2010 campaign was certainly not the first time that the Conservatives had promised a more restrictive immigration regime. Famously, and counter-productively insofar as it was subsequently said to have contributed to their 'nasty party' image, the Conservatives ran with the slogan 'it's not racist to impose limits on immigration' in the 2005 election campaign (Conservative Party 2005: 18). The manifesto commitments of that year included a pledge to withdraw from the 1951 Geneva Convention on Refugees and to set a fixed quota for asylum seekers, as well as a commitment to set an overall annual limit to the number of immigrants.

The 2010 manifesto dropped the proposals on refugees and asylum-seekers (who were by now less of a political issue) and changed the tone in line with Cameron's attempt to 'decontaminate' his party's brand: for example, the section dealing with immigration was entitled 'attracting the brightest and best to our country', a mantra that could have come straight from the New Labour hymnbook. Despite this, nearly all of the policy proposals were about restricting rather than encouraging immigration. Similarly to 2005 , the 2010 manifesto promised that a Conservative government would set an annual limit on the number of non-EU economic migrants, as well as apply transitional controls in the future on all new EU member states. On family migration, the party committed itself to introducing an English language test for all migrants coming to get married, and while a substantial section on student migration promised to make it easier for 'reputable 
universities and colleges' to accept overseas students, it outlined a number of measures to tackle abuse of the student route (Conservative Party 2010: 21 ). ${ }^{1}$

In stark contrast, the Liberal Democrats' position on immigration was, on the face of it, one of the most permissive seen in any mainstream party manifesto in recent times. The Lib Dems had, like their opponents, accepted Labour's points based system and 'managed migration' more generally. However, far from promising to roll back the liberalisation of economic migration that had occurred under Labour, the Liberal Democrat manifesto proposed to extend it into two areas where Labour had been keen to be seen as tough - asylum and irregular migration. The proposals included a regularisation programme for irregular immigrants who had been living in the UK for over ten years and a number of progressive asylum measures, including taking asylum decision-making away from the Home Office, support for a more coordinated EU asylum system, allowing asylum-seekers to work, ending the detention of children in immigration detention centres, and reduced use of deportation and detention (Liberal Democrats 2010: 75-77). These commitments were hedged by a couple of more control-oriented policies - notably, the proposed reintroduction of exit checks and police powers for a National Border Force - and by a proposal to introduce a regional points-based system. However, the concrete proposals, as well as the absence of any restrictions on economic migration or international students, could hardly have been more different to the Conservatives' position. Whatever else the Liberal Democrats' position was, it was certainly not in tune with the decidedly restrictionist and populist tone of most print media coverage of immigration. In the televised leader's debates, the Liberal Democrat leader, Nick Clegg, had distanced himself from the Conservatives' headline policy, saying 'we can't come up with promises like caps [on immigration], which don't work' (TV debate 29 April 2010), while his party's promise of an 'amnesty' for irregular migrants was the main focus for the ferocious attack that the Tories and their allies in the media mounted after Clegg's stand-out performance in the first debate sparked a phenomenal (albeit temporary) rise in the Lib Dem's poll ratings. 
It was clear, then, that the two parties had very different positions on immigration. But which of their respective election commitments made it into the coalition programme? And why?

Undoubtedly the most significant commitment in terms of subsequent policy developments was the inclusion of the Conservative pledge to introduce an annual limit on non-EU economic migrants, with a claim that the mechanisms to achieve this would be 'jointly' considered. The numerical target to reduce net migration to 'tens of thousands' was not included in the programme: the Lib Dems regarded it as unworkable and even some Conservatives worried it was a hostage to fortune. That pledge, though, was nevertheless subsequently repeated by Conservative ministers so often that in spite of protestations from the Liberal Democrat Business Secretary, Vince Cable, that it was not a coalition policy, it effectively became one. The Conservative pledge to introduce transitional controls on future EU member states as a matter of course was also included. In contrast, with the exception of a commitment to end child detention, the only Liberal Democrat manifesto commitments that made it into the coalition programme were the border control measures. The progressive commitments on asylum and the proposed regularisation programme were dropped completely, as was the regional points based system. In two other areas where the Conservatives had promised restrictive policies but the Liberal Democrats had said nothing - international students and family migration - the coalition agreement was rather vague: it contained a pledge to 'minimise abuse' of the immigration system including student routes, and a promise to 'explore new ways to improve the current asylum system' (HM Government, 2010).

Though many right-wing Tories claim to see the liberalising influence of Nick Clegg and his colleagues on everything the Coalition says and does, in the field of immigration it is clear that the Conservatives set the agenda. This was further reinforced by the allocation of ministerial portfolios. The positions of Home Secretary and Immigration Minister (a junior ministerial post within the Home Office) both went to Conservatives - Theresa May and Damian Green respectively. The only senior Liberal Democrat with a ministerial portfolio that really touched on immigration was Vince Cable, the Business Secretary, although his ministry, the Department for Business, Innovation and 
Skills (commonly known by its acronym, BIS), also provided a home for David Willetts, a junior minister responsible for Universities and Science and a Conservative MP. Disagreements between the Home Office and BIS would become a significant fault line in coalition debates over immigration. But the situation in May 2010 was clear: in all but name, the coalition's immigration policy was a Conservative immigration policy. ${ }^{2}$

This was in no small way down to the fact that, right from the start of the negotiations, the Conservatives, who brought by far the majority of seats to the coalition, insisted that immigration was one of the 'red-lines' that they would not cross in order to do a deal (see Hazel and Yong, 2012, Wilson, 2010: 249, Laws 2010: 184). These non-negotiables proved crucial because the Liberal Democrat negotiating team - a team which, incidentally, excluded Vince Cable - seemed to have made up its mind early on that it could not afford to fight a second election and that (either for ideological or for arithmetical reasons, or perhaps both) it was going to have to govern with the Tories rather than with Labour (Adonis, 2013; Wilson, 2010; Laws, 2010). The Lib Dem negotiators (some of whom were never fans of their manifesto proposals on immigration anyway) were under no illusion either, given the brutal treatment handed out to those proposals during the election by the media and the negative reaction to them in polls and focus groups, that public opinion was on their side. Hardly surprising, then, that they were willing to let them slip away, preferring to focus their efforts on securing 'wins' which might eventually secure them some credit with 'their' voters in particular their plan to end child detention. As for the promise to make big reductions in numbers coming in, if it was achieved, then it would do the Coalition no harm; if not, it would probably be the Conservatives who got the blame. Lib Dems also took comfort in the fact that there would be no actual cap on international students - one of the biggest and economically most important components of immigration - even if they were included in any overall target. It is also important to remember, when trying to explain the deal that was done, that, as in many other areas, the Lib Dems were not especially well-prepared for negotiations, that they were up against the clock given both parties' desire to conclude an agreement quickly, and that - understandably - they chose to 
devote what limited time they had to securing their main priorities, of which immigration was not one.

\section{Immigration policy under the coalition}

Before examining the transposition of the coalition's programme into policy, and the factors that have influenced this process, we briefly sketch what the government has done to date. In other words, what changes there have been to our dependent variable - immigration policy outputs. It is quite clear that the motor propelling the coalition's immigration policy is the net migration target. If the promise to more than halve net inflows over five years was to be redeemed, significant restrictive changes to the immigration system inherited from Labour were inevitable. Emigration is not something the government can do much about. The same goes for the entry of EU citizens, although, in an attempt make the UK a less attractive destination for migrants from Romania and Bulgaria (the transitional controls on which lapsed in January 2014), an inter-ministerial group was set up to explore welfare restrictions for EU migrants, which culminated in an announcement by David Cameron in November 2013 that the government would exclude new arrivals from publiclyfinanced housing benefit and jobseeker's allowance (unemployment benefit) for three months. This aside, the coalition has mainly focused its attention on reducing non-EU immigration in three areas where it does have the capacity to influence admissions: work-related migration, family migration, and foreign students.

The main restrictions on labour migration include the closure of the Tier 1 general route, which had allowed highly skilled non-EU migrants to enter the UK without a job offer; the introduction of an annual cap on the number of Tier 2 non-EU skilled labour migrants with a job offer (set at 20,700 for the year from 6 April 2013 to 5 April 2014); and a raising of the shortage occupation list (which allows employers to bring in foreign workers without a labour market test, but only for specific occupations where there are not enough resident workers) to graduate-level jobs only. The main changes to family migration routes have seen a substantial increase in the financial requirements for 
those wishing to bring family members to the UK and the introduction of a English language requirement for foreign spouses and civil partners. Student migration policy has also been significantly tightened. While several of the developments in student migration have been about tackling abuse of student routes, it is clear that there is also a distinct (if sometimes complementary) imperative to reduce numbers, which is unsurprising given that students are the largest migrant category. To this end, the coalition has abolished the Tier 1 post-study work route, under which foreign students could stay and look for work after finishing their studies, and introduced new rules that require foreign students who wish to stay in the UK after graduation to acquire a skilled job offer from an employer. The government has also increased the financial and language requirements for overseas students, and increased the restrictions on certain students' rights to work or bring dependent relatives. In addition to these policy changes there has been an increase in scrutiny of institutions sponsoring foreign students. Most of this focused on private colleges and language schools, where most abuse of the system was deemed to be taking place, but in August 2012 the UKBA took the dramatic and controversial step of suspending London Metropolitan University's licence to sponsor visa applications (since reinstated). Finally, the 2013 Immigration Bill, which at the time of writing is still being debated in Parliament, includes a number of provisions to make it easier to remove irregular immigrants, for example by limiting rights of appeal against removal decisions, and measures to restrict access to public services and the labour market (though of course irregular migrants do not count in the net migration target).

\section{From the coalition agreement to policy outputs}

Having won the first round of the coalition tussle over immigration policy, it remained to be seen whether the Conservatives would be able to deliver their election commitments in government. The transition from electoral politics to governing is no small step. Whereas voters are the principal, even sole, audience for parties' political communications during election campaigns, in government parties must engage with a range of affected interests, which are often highly organised and well- 
resourced. Indeed, one influential model of immigration politics argues that it is the discrepancy between the restrictive preferences of the 'unorganised public' and the pro-immigration preferences of the 'organised public' (principally business interests) that accounts for why restrictive political discourse does not translate into equally restrictive policy outputs (Freeman, 1995). Under the previous Labour government, pro-immigration 'clients' such as the Confederation for British Industry (CBI), the Federation of Small Businesses (FSB) and several sector-specific industry associations, such as the British Hospitality Association and the National Farmers' Union, had become increasingly active on the immigration issue. Although these groups did not drive Labour's liberalisation of economic migration routes, they certainly influenced policy through both formal consultations and informal lobbying (Consterdine and Hampshire, 2013; Somerville, 2007: 108; Balch, 2009). These groups might have been expected to mobilise against the new government's commitment to restrict immigration.

Furthermore, it remained to be seen how the broad-brush commitments of the coalition agreement would be translated into detailed policies inside the governmental machinery. Though the Liberal Democrats had signed up to a Tory agenda on immigration in late May 2010, there was still potential for subsequent negotiations over policy specifics to reignite disagreements between the coalition partners. And, as immigration is an issue that cuts across departmental boundaries and often reveals disagreements between departments (for example, between control-oriented interior ministries and pro-immigration business or finance ministries), intra-executive disputes were also a possibility. These different dimensions of potential intra-coalition conflict - partisan differences and functional logics - may be self-reinforcing or have a tendency to cancel one another out, depending on whether the allocation of ministerial portfolios maps party ideology onto bureaucratic function. In short, the transposition of election pledges into policy outputs is influenced by a number of intervening variables, a complex interplay of non-governmental influences and intra-coalition dynamics. To unpack these interrelationships and their causal impact on policy outputs, we examine 
to what extent non-governmental actors influenced immigration policymaking (for example, by tempering the coalition's restrictive agenda), how intra-coalition dynamics (in terms of partisan and interdepartmental divisions) shaped outputs, and the how these different factors interacted with one another.

The role of interest groups

There is clear evidence that lobbying by employers tempered the government's original proposals on economic migration. The proposals on work-related routes were put out for consultation in late June 2010, including inter alia: proposals to raise the minimum criteria for qualification under Tier 1; a monthly quota for skilled workers under Tier 2; a merger of the Shortage Occupation and Resident Labour Market Test routes; increased English language requirements for Tier 2 applicants; and the inclusion of intra-company transferees within the annual cap. The level of the annual cap was also put out for separate consultation. The proposals met with strong and often public opposition from a number of employers' associations, including the CBI and FSB, sectoral organisations, and numerous large corporations, among them Asda (owned by Walmart), BT, Deutsche Bank, General Electric, GlaxoSmithKline, Honda, JP Morgan, Microsoft UK, Nissan, Siemens, and Toyota. Furthermore, several overseas governments, notably the Indian government during a high profile trade mission led by David Cameron, expressed their concern about what Anand Sharma, India's Commerce Minister, described as the potential 'adverse effect' on trade relations (see Bale and Hampshire 2012).

The government responded with a public relations offensive - Damian Green, then Immigration Minister, was dispatched to India to allay concerns and gave a speech insisting that the UK would remain 'open for business' (Green 2010). More importantly, several of the proposed restrictions were amended or dropped altogether. Although the Tier 1 General Route for highly-skilled workers was closed and an annual quota was established for Tier 2, the latter was set at a relatively high level (which has not been exceeded to date and has not therefore curtailed the number of skilled migrant 
workers) and the former was not something employers were especially concerned about as it did not affect their ability to recruit overseas workers. Further, following lobbying by several banks and law firms in the City, foreign workers earning over $£ 150,000$ were exempted altogether from the annual cap - meaning companies can still recruit as many workers as they wish at this level - and even more significantly in terms of migrant numbers, multinationals were successful in their efforts to have intra-corporate transferees excluded from the cap. Thus work-related migration policy has been tightened, as the Conservatives promised, but significantly less than they originally intended after intensive lobbying by business. There is nothing especially unusual or surprising about this: such lobbying is particularly likely to succeed if those doing it can credibly tell government that what it intends to do will have a negative impact in an important area that it knows more about than ministers (see Bernhagen, 2013). However, it does illustrate the role of interest groups as intervening variables in the translation of election pledges into policy outputs - something that is surely important if we want to understand how and why (rather than just whether) parties matter for policy.

Indeed, if we compare the significant concessions made to the work-related proposals with the more direct translation of the government's pledges on family migration we can see the differential effect of interest groups between subfields of immigration policy. In the case of family migration policy, where there are fewer and certainly less influential interest groups, the government's original proposals have been largely implemented. The commitment to introduce English language requirements for foreign spouses and civil partners, though strongly opposed by migrants' rights groups and other NGOs, was swiftly implemented with no formal consultation (the policy was announced on 9 June 2010 and came into force on 29 November 2010). Similarly, the increased financial requirements for those wishing to bring family members to the UK were firmly opposed by NGOs, but implemented with no significant concessions. 
The amount of concessions won by affected interests in the area of student migration sits somewhere between economic and family migration policy. There has been significant and increasingly vocal opposition from the higher and further education sectors to government policy on international students (see, recently, Universities UK, 2013). And MPs and Lords, including Conservatives and Liberal Democrats, have also criticised the government for, they argue, damaging one of the UK's largest export industries. No fewer than five parliamentary committees have urged the government to remove international students from the net migration figures to prevent downward pressure from negatively affecting student recruitment. In response, the government has made a few minor concessions, but far fewer than on work migration. In particular, it has refused to remove students from the net migration figures and it has pressed ahead with several of its more restrictive policies.

There are a number of reasons why the education lobby and its parliamentary supporters have been unable to wring as many concessions as business achieved on labour migration. First, according to senior officials that we interviewed, Universities UK and the education sector as a whole is less used to lobbying and is not yet as effective as business at doing so, often achieving a degree of publicity but relatively little leverage. For instance, the sector has not managed (and may not even have tried) to persuade the Home Office to task the government's Migration Advisory Committee (MAC) to look into the issue and make recommendations. Second, notwithstanding criticisms from parliamentary committees, there has been relatively little pressure and no organised campaign from MPs sitting in what are sometimes thought of as 'university seats' - partly because they come from different parties and partly because it is not always easy, given that a town or city's university institutions and student population may be spread across several parliamentary constituencies, to identify a particular MP as the representative of the university or universities concerned. There is also little evidence of HE lobbyists targeting their efforts at either Conservative MPs, or at those Tories in the Number Ten Policy Unit charged with writing the Party's next manifesto. Third, there was significant resolve in government to put downward pressure on students because if total immigration was to be 
reduced, it would be crucial to cut student numbers since they represented the largest single inflow. Moreover, many in government believed that there really was significant abuse of the system, particularly in the further education and language school sectors. Recent statistics indicate that the government has successfully tightened student migration policy, especially in the latter sectors: in the year to March 2013, 206,814 study visas were issued, which was a fall of 9 per cent overall compared with the previous 12 months, but the falls in the further education and language school sectors was 46 per cent, against a 5 per cent increase in the university sector (ONS 2013). The latter increase - and the fact that there is no actual cap on international students, even if the numbers coming in are included in the government's net target - probably undermined HE lobbyists' efforts to ease what they continue to argue is still a restrictive regime.

In summary, the lesser influence of the education compared to the business lobby on the coalition's immigration policy shows that not all pro-immigration clients are equal; their influence is not a straightforward consequence of the distribution of costs and benefits of a given policy, as Freeman (1995) has argued, but is also influenced by the opportunity structures that client groups face and the lobbying strategies that they adopt in light of these structures. At the same time, since the degree and scope of organized interests' influence varies not only between countries but also between policy subfields within a given country, any attempt to read off partisan influence by simply comparing pledges and outputs risks obscuring an important intervening variable with differential incountry as well as cross-national effects.

\section{Intra-coalition dynamics}

Assessing partisan influence on policy in the context of coalition government is further complicated by intra-coalition dynamics. While tensions in the UK Coalition are often depicted in the media as evidence of partisan or ideological conflict between the coalition partners (perhaps especially so in the UK, where coalition is a relative novelty), our interviews revealed that it is not always easy to unpick party conflict from inter-departmental turf wars. When, for example, a Conservative minister 
from the Home Office encounters opposition from a Liberal Democrat at the Department for Business, Innovation and Skills, it is often difficult (and requires in-depth case knowledge) to assess whether partisan influence or conflicting departmental agendas, or both, are at stake. Ministers will have their own ideological leanings, of course, but given their reliance on officials in the process of translating broad electoral promises into detailed policy outputs (Page 2012), it is likely that departmental policy agendas play a significant role in these disputes. This observation is further supported by the sometime disagreement between ministers from the same party based in different departments.

In the present case, there has certainly been debate and disagreement within the coalition about immigration policy, both behind the scenes and in public. Vince Cable in particular has persistently stated that the net migration target is not, in fact, coalition policy and he has openly criticised senior Conservative's statements on immigration. For example, he described a major speech about immigration given by the Prime Minister shortly before the April 2011 local elections as 'very unwise' and in March 2013 said that if net migration was reduced to below 100,000 'enormous damage would be done' (Waugh and Macrory 2013). The core problem according to Cable, as he told a group of Indian journalists at Heathrow Airport, is that the government is 'trying to reconcile two different objectives, one of which is to reassure the British public that immigration is under control, and the other is to have an open economy where we can bring the talents from around the world' (quoted in Barker 2010). In the wake of a big drop in the numbers of students coming to the UK from India, Cable has also criticised media coverage (and by implication Conservatives who have helped stoke it) of the news that overseas student numbers were coming down: students he claimed had been caught up in a 'very torrid and emotional debate in the UK. When... the number declines, this is [seen as] a great triumph for immigration control - which is quite absurd and unfortunately is seriously distorting the debate on sensible university policy and sensible immigration policy' (see Adams, 2013). 
Cable and other Liberal Democrat ministers have made several attempts to constrain Conservative policies - and with some effect. On labour migration, Cable played an important role expressing the opposition of business to the cuts to work-related routes and persuaded the Conservative Home Secretary, Theresa May, to accept the exclusion of intra-corporate transferees and workers earning over $£ 150,000$ from the skilled workers cap. And in the rather different context of the ministerial group examining cuts to benefits and social services for migrants, David Laws, the Liberal Democrat Schools Minister, seems to have successfully resisted Home Office proposals to exclude the children of illegal immigrants from schools (Watts, 2013).

Yet despite these examples of Liberal Democrats constraining Conservative proposals, two things seem clear. First, on balance the Liberal Democrats have not been able significantly to constrain the Conservatives' determination to reduce net migration through more restrictive immigration policies; and second, insofar as intra-coalition disagreements have constrained restrictions they have been driven as much by inter-departmental logics as ideological or partisan conflict. To be sure, what is sometimes presented in the media as Cable's running battle with Theresa May has a partisan dimension, and given their apparent leadership ambitions it may also be about personal positioning within their own parties. But it is equally, if not more, a conflict between two government departments with very different views of immigration: a control-oriented and media-sensitive Home Office versus a liberal-inclined and economistic Department for Business. It is notable that Cable's statements on what he calls the 'inherent tension' (Waugh and Macrory 2013) between the Home Office's obsession with reassuring the public that immigration is under control on the one hand, and the need to allow UK higher education and business to recruit the people they need on the other, frame the conflict in functional rather than partisan terms.

This is not to say that the personal views, ideological leanings, or party ambitions of the key actors are irrelevant; rather that, as ministers, they often read from a script written by government mandarins and affected interests rather than party strategists. It is also worth noting that tensions 
within the Conservative Party, tensions that are found in many centre-right parties on immigration policy (Bale 2008) reflect these functional dilemmas, too. Most obviously, David Willets, the Universities Minister, has not gone along quietly with Home Office plans to reduce student numbers, and it is noticeable that the reductions have come mainly at the expense of further education and language schools, rather than tertiary institutions, even if the latter may suffer in the long-term as 'feeder' colleges produce fewer students. Indeed, Cable's and Willets' shared concern about the economic impact of immigration restrictions has been the basis of an occasional inter-party alliance against May and Green (and his successor as Immigration Minister, Mark Harper) at the Home Office. For other Conservative Ministers, resistance to the demands of the Home Office may have more to do with (what they see) as administrative common sense combined with an inherent distaste for 'red-tape' that reduces economic freedom and therefore growth: the resistance from Communities Secretary, Eric Pickles, usually portrayed as a no-nonsense right winger, on the proposed requirement that all private landlords check the immigration status of their tenants is a case in point (see Hope, 2013). As several of the senior advisors we spoke to pointed out, opposition to Home Office proposals from a range of ministers - both Conservative and Liberal Democrat - has led the Prime Minister to complain on more than one occasion that some members of the Cabinet seem intent on undermining the government's net migration pledge.

Yet the Home Office remains the 'big beast' in the UK government jungle when it comes to immigration - certainly much bigger than BIS. Even if the latter makes the argument for a less restrictive stance on international students, the former is likely to get its way, not least since the Home Secretary can claim that she is delivering on one of her party's flagship manifesto commitments - one that enjoys support from voters and, as such, is a priority for the Prime Minister, who as several of our interviewees told us, has often supported her in inter-departmental disputes. This presumes, of course, that such disputes always involve consultation of other departments. On some occasions they do: in the case of student migration, there are formal (though not routine) meetings at Minister of State Level. On the other hand, there have been occasions where the lack of 
consultation - or even just prior notice - has been marked, even shocking. BIS, for example, was given no warning when the Home Office decided to suspend London Metropolitan University's licence to admit international students on the grounds that it was not doing all it should to monitor students - a decision that, even though the suspension turned out to be fairly short-lived, garnered widespread and hugely negative publicity in the Indian sub-continent, and may have contributed to the UK's declining share of that market.

However, the deeply-entrenched departmental pecking order at the heart of Whitehall is only part of the explanation for the apparent inability of the Liberal Democrats to exert much influence on coalition immigration policy. And even their inexperience, their supposed ineptitude at playing the governmental game, and their relative lack of resources (Hazell and Yong, 2012, passim) can only take us so far. What also matters is their sense, as a political party trying to learn from the past and thinking about the future, of what may benefit or damage them electorally. In this respect, some Liberal Democrats have been secretly relieved to find themselves only occasionally playing the role of the coalition's 'progressive', if largely ineffectual, conscience. As one Liberal Democrat advisor told us, the party's immigration commitments did not go down well during the 2010 campaign, and there was considerable relief among some in the leadership that they were able to drop them with comparatively little fuss as part of the coalition agreement. Given the state of public opinion on the issue, there is so little electoral advantage in adopting permissive immigration measures that a degree - but no more than a degree - of resistance to Conservative-led restrictions arguably allows the party to pacify its liberal activists while remaining sufficiently under the radar as far as most voters are concerned to avoid the kind of backlash that arguing loudly for, let alone actually implementing, truly liberal policies might create.

Even this may be underplaying things, since there are signs that the Liberal Democrats are repositioning themselves on immigration. Increased public support for UKIP, which is now as much an anti-immigration as an anti-EU party, has prompted all mainstream parties to reassert their 
credentials on immigration. The Liberal Democrats hung on to their seat at the high-profile Eastleigh by-election in February 2013, but UKIP came in second on a 19.3\% swing. And the local elections in spring 2013, UKIP gained 139 councillors in England and Wales, with the Conservatives and the Liberal Democrats losing 335 and 124 respectively. It is no coincidence that sandwiched between the Eastleigh result and the local elections, Nick Clegg, the Deputy Prime Minister, broke his silence on immigration with a speech that was a far cry from the pledges of regularisation programmes and liberal asylum measures in the 2010 manifesto. Instead, the centrepiece of his speech was a proposal that the government would require $£ 1,000$ deposits for visa applicants from 'high-risk' countries, with the money being repaid only when they leave the UK. Clegg's speech went down very badly with party activists: according to one insider, it was roundly criticised at the Party's federal policy committee. The visa bond proposal was certainly a hastily developed idea, apparently dreamed up by an adviser with some personal experience of the existing visa system. However, the Party itself was not the intended audience. The leadership was more concerned about internal qualitative and quantitative research which confirmed impressions gained on the doorstep that large numbers of voters who had or would consider voting Lib Dem saw immigration as a big issue, rationalising their concerns as worries about pressures on schools, housing and health services. And Clegg's subsequent support for the government's proposed benefit restrictions for EU migrants signalled an even bigger shift from the progressive tone of the 2010 manifesto.

\section{Conclusion: parties matter ... to a point}

In this paper we have examined partisan influence on immigration policy by tracing the process through which electoral pledges were (or were not) translated into UK coalition government policy. We conclude with some observations on the implications of our case for understanding partisan influence on public policy in general and immigration policy in particular.

First, it is striking that despite the formation of a coalition between two parties with opposed policy positions, as well as interest group lobbying and intra-coalition conflicts in government, partisan 
influence on immigration policy is evident. In the early 2000 s, the Labour government liberalised immigration policy (see Consterdine and Hampshire 2013, Somerville 2007, Spencer 2011) and the coalition has clearly introduced a more restrictive agenda. Despite its reliance on coalition partners with a more liberal policy and despite significant opposition from pro-immigration interest groups, the Conservative Party has been able to transpose its core election pledges into policy outputs. In short, we find evidence of partisan influence on policies and, insofar as those policies are at least partially responsible for the reduction in immigration flows, on outcomes as well.

Our analysis therefore throws doubt on the migration literature that downplays the significance of political parties for immigration policy outputs as well as outcomes, whether due to the lock-in effects of previous policy decisions (Hansen 2002) the influence of pro-immigration clients (Freeman 1995), or the supposed inability of governments to influence migration flows. The fact that UK immigration policy has gone from being one of the most restrictive anywhere in Europe during the 1980 s, to one of the most liberal under Labour in the early 2000s, and has now moved back in a more restrictive direction under a Conservative-led coalition since 2010 undermines the idea that there is a structural 'expansionary bias' in immigration policymaking (Freeman 1995). In the UK's majoritarian democracy, immigration policies move sometimes in an expansionary direction, sometimes in a restrictive direction; and which party or parties are in government matters for explaining this. Further, although other non-policy factors no doubt play a role, the fact that numbers have come down in those areas where policy has been most significantly tightened, namely family and non-tertiary student migration, shows that governments are far from powerless in influencing migration outcomes.

However, our case also illustrates how partisan influence on immigration policy outputs is mediated and constrained. Partisan influence has been mediated as much by functional dilemmas manifested through inter-departmental disagreements as by political differences between the coalition partners (though the former are sometimes reinforced or presented as partisan differences 
depending on ministerial portfolios). The variation between policy subfields (e.g. work, student, and family migration) shows it has also been heavily mediated by organized interests. To understand the degree to which electoral pledges influence policy outputs therefore requires examination of the interplay between partisan change, interest groups, and interdepartmental conflict. Our case suggests that while it is sometimes possible to parse these different elements, often it is not. Indepth process tracing allows us to see these complex dynamics, which easily get lost in large $n$ comparisons of pledges and outputs, let alone outcomes. At the same time, our case reveals limitations of scholarly approaches to immigration that focus on one or the other of the factors outlined above: political economists on employers and other lobby groups; party scholars on political parties; and institutionalists on functional and bureaucratic conflict. In the search for parsimonious explanations a lot of non-trivial complexity gets lost. Each of the above approaches has considerable merits, but can provide at best a partial picture of how politics shapes immigration policy outputs. Our aim should be to combine them, without losing sight of the wood for the trees. 


\section{References}

Adams, Richard (2013). "Immigration: Cable: UK has been hurt by student visa changes", Guardian, 30 May.

Adonis, Andrew (2013). Five Days in May: the Coalition and Beyond. London: Biteback.

Ashcroft, Lord (2013). Small Island: Public opinion and the politics of immigration. London: Lord Ashcroft Polls, http://lordashcroftpolls.com/wp-content/uploads/2013/08/LORD-ASHCROFTPublic-opinion-and-the-politics-of-immigration2.pdf

Balch, Alex (2009). "Labour and Epistemic Communities: The Case of Managed Migration in the UK", British Journal of Politics and International Relations, 11:4, 613-633.

Bale, Tim (2008). "Turning Round the Telescope: Centre-right Parties and Immigration and Integration Policy in Europe", Journal of European Public Policy, 15:3, 315-330.

Bale, Tim (2013). “More and More Restrictive-But Not Always Populist: Explaining Variation in the British Conservative Party's Stance on Immigration and Asylum", Journal of Contemporary European Studies, 21:1, 25-37.

Bale, Tim, James Hampshire, and Rebecca Partos (2011). “Having One's Cake and Eating it Too: Cameron's Conservatives and Immigration", The Political Quarterly, 82:3, 398-406.

Bale, Tim, and James Hampshire (2012). "Easier Said than Done? The Conservatives, the Coalition, and Immigration Policy", in T. Heppell and D. Seawright (eds.), Cameron and the Conservatives. Basingstoke: Palgrave. 
Barker, Alex (2010). "Five Elephant Traps for Cameron in India", Financial Times Westminster Blog, 27 July 2010, http://blogs.ft.com/westminster/2010/07/five-elephant-traps-for-cameron-inindia/

Beach, Derek and R. B. Pedersen (2012). Process Tracing Methods: Foundations and Guidelines. Ann Arbor: University of Michigan Press.

Bernhagen, Patrick (2013). "When do Politicians Listen to Lobbyists (and who benefits when they do)?", European Journal of Political Research, 52:3, 20-43.

Boswell, Christina (2009). The Political Uses of Expert Knowledge: Immigration Policy and Social Research. Cambridge: Cambridge University Press.

Conservative Party (2005). It's Time for Action: The Conservative Election Manifesto 2005. London: The Conservative Party.

Conservative Party (2010). Invitation to Join the Government of Britain: The Conservative Manifesto 2010. London: The Conservative Party.

Consterdine, Erica, and James Hampshire (2013). “Immigration Policy Under New Labour: Exploring a Critical Juncture", British Politics, doi: 10.1057/bp.2013.19.

Ellermann, Antje (2009). States against Migrants: Deportation in Germany and the United States. Cambridge: Cambridge University Press.

Freeman, Gary P. (1995). "Modes of Immigration Politics in Liberal Democratic States", International Migration Review, 29:4, 881-902.

Ford, Robert, Will Jennings, and Will Somerville (forthcoming). "Public Opinion, Responsiveness and Constraint: Britain's Three Immigration Policy Regimes", Journal of Ethnic and Migration Studies. 
Galbraith, John K. (1969). Ambassador's Journal: A Personal Account of the Kennedy Years. London: Hamish Hamilton.

George, Alexander L., and Andrew Bennett (2005). Case Studies and Theory Development in the Social Sciences. Cambridge, Mass: MIT Press.

Green, Damian (2010). "The Real Immigration Question", speech to the Royal Commonwealth Society', 6 September 2010, http://www.homeoffice.gov.uk/mediacentre/speeches/Damian-Green-real-immigration

Hampshire, James (2013). The Politics of Immigration: Contradictions of the Liberal State. Cambridge: Polity.

Hansen, Randall (2002). “Globalization, Embedded Realism, and Path Dependence: The Other Immigrants to Europe", Comparative Political Studies, 35:3, 259-283.

Hazell, Robert and Ben Yong (2012). The Politics of Coalition: How the Conservative - Liberal Democrat Government Works. London: Hurst.

HM Government (2010). The Coalition: Our Programme for Government. London: Cabinet Office. Hope, Christopher (2013). "Plans to force millions of private landlords to carry out immigration checks on tenants to be watered down", Daily Telegraph, 27 May, http://www.telegraph.co.uk/news/politics/10081678/Plans-to-force-millions-of-privatelandlords-to-carry-out-immigration-checks-on-tenants-to-be-watered-down.html

Imbeau, L. M., F. Pétry, and M. Lamari (2001). “Left-right Party Ideology and Government Policies: A Meta-analysis", European Journal of Political Research, 40:1, 1-29.

Ivarsflaten, Elisabeth (2005). "Threatened By Diversity: Why Restrictive Asylum and Immigration Policies Appeal to Western Europeans", Journal of Elections, Public Opinion, and Parties, 15:1, 21-45. 
Jennings, Will (2010). "Bureaucratic Performance and Control in British Politics: Asylum Policy 19942007", British Journal of Politics and International Relations, 12:4, 539-568.

Joppke, Christian (1998). "Why Liberal States Accept Unwanted Immigration", World Politics, 50:2, 266-293.

Knill, Christoph, Marc Debus, and Stephan Heichel (2010). “Do Parties Matter in Internationalised Policy Areas? The Impact of Political Parties on Environmental Policy Outputs in 18 OECD Countries, 1970-2000", European Journal of Political Research, 49:3, 301-333.

Laver, Michael, and Kenneth A. Shepsle (1994). Cabinet Ministers and Parliamentary Government. Cambridge: Cambridge University Press.

Laws, David (2010). 22 Days in May: The Birth of the Lib Dem-Conservative Coalition. London: Biteback.

Liberal Democrats (2010). Liberal Democrat Manifesto 2010. London: Liberal Democrats.

Lijphart, Arend (2012). Patterns of Democracy: Government Forms and Performance in Thirty-six Countries, $2^{\text {nd }}$ Edition. New Haven, CT: Yale University Press.

Lipsmeyer, Christine S., and Heather Nicole Pierce (2011). "The Eyes that Bind: Junior Ministers as Oversight Mechanisms in Coalition Governments", Journal of Politics, 73:4, 1152-1164.

Mair, Peter (2008). "The Challenge to Party Government", West European Politics, 31:1, 211-34. Mclaren, Lauren, and Mark Johnson (2007). “Resources, Group Conflict and Symbols: Explaining Anti-immigration Hostility in Britain", Political Studies, 55:4, 709-732.

Migration Watch (2013). "Immigration and Visa Statistics", 23 May 2013. 
Office for National Statistics (ONS) (2013). Migration Statistics Quarterly Report, May 2013, available at http://www.ons.gov.uk/ons/rel/migration1/migration-statistics-quarterly-report/may2013/msqr-may13.html\#tab-Summary-statistics

Page, Edward (2011). "The Civil Servant as Legislator: Law-making in British Administration", Droit et Societe, 79:3, 637-655.

Page, Edward (2012). Policy without Politicians: Bureaucratic Influence in Comparative Perspective. Oxford: Oxford University Press.

Pollard, Stephen (2013). "Immigration: The Coalition is Making Real Progress Now", Daily Express, 25 May 2013, available at http://www.express.co.uk/comment/expresscomment/402442/Immigration-The-coalitionis-making-real-progress-now

Richardson, Jeremy, and A. G. Jordan (1979). Governing under Pressure: The Policy Process in a PostParliamentary Democracy. Oxford: Martin Robertson.

Rose, Richard, and Phillip Davies (1994). Inheritance in Public Policy: Change without Choice in Britain. New Haven: Yale University Press.

Schmidt, Manfred G. (1996). "When Parties Matter: A Review of the Possibilities and Limits of Partisan Influence on Public Policy", European Journal of Political Research, 30:2, 155-183.

Sides, John, and Jack Citrin (2007). “European Opinion about Immigration: The Role of Identities, Interests, and Information", British Journal of Political Science, 37:3, 477-504.

Somerville, Will (2007). Immigration under New Labour. Bristol: Policy Press.

Spencer, Sarah (2011). The Migration Debate. Bristol: Policy Press. 
Streeck, Wolfgang, and Kathleen Thelen (eds.) (2005). Beyond Continuity: Institutional Change in Advanced Political Economies. Oxford: Oxford University Press.

Thomson, Robert (2001). “The Programme to Policy Linkage: The Fulfilment of Election Pledges on Socio-economic Policy in The Netherlands, 1986-1998", European Journal of Political Research, 40:2, 171-197.

Transatlantic Trends (2010). Transatlantic Trends: Immigration 2010, German Marshall Fund of the United States. http://trends.gmfus.org/archives/immigration-archive/immigration-2010/

Universities UK (2013). “Universities UK Concerned by Government's Stance on Net Migration Target", Press Release, 26 February.

http://www.universitiesuk.ac.uk/highereducation/Pages/GovernmentNetMigrationRespons e.aspx

Watts, Nicholas (2013). "David Laws Vetoes Plan to Force Schools to Check Immigrant Status of Pupil', The Guardian, 22 May.

Waugh, Paul and Sam Macrory (2013). 'Vince Cable: Show me the Honey', The House Magazine, 21 March. http://www.politicshome.com/uk/article/74884/vince_cable_show_me_the_honey.html Wilson, Rob (2010). Five Days to Power: The Journey to Coalition Britain. London: Biteback.

\footnotetext{
${ }^{1}$ The specific proposals included a bond for foreign students at new or unregistered institutions, a requirement for foreign students to demonstrate financial means of support, and a requirement that students must usually leave the country and reapply if they wish to switch to another course or apply for a work permit. This latter commitment meant closing the post-study work route established by Labour, under which foreign graduates could stay and look for work for up to two years after finishing their studies.
} 
2 This statement stands in apparent contrast with the claim by the authors of one of the most impressive works to date on the working of the Coalition (which admittedly makes very few mentions of immigration) that the origin of the policies in the relevant section of its Programme for Government was 'one-third from the Tory manifesto, one-third from the Lib Dems, and one-third from both' (Hazell and Yong, 2012). The difference is largely methodological: they simply enumerate policies in the agreement based on their manifesto origins without giving a relative weight to any of the proposals. We would contend that inclusion of an annual limit on economic migrants, for example, should be given more weight in any evaluation of partisan influence than some of the less significant commitments taken from the Lib Dem manifesto. 